\title{
Developing Discharge Guidelines for Patients Undergoing Laparoscopic Cholecystectomy
}

\author{
Asmaa A. Kadous, Soad M. Hegazy, Tarek S. El-Hosieny, \\ Bahia G. Abd El-Razik \\ B.Sc. Nursing, Faculty of Nursing, Alexandria University; Prof. of Medical Surgical \\ Nursing, Faculty of Nursing -Ain shams university; Assist. Prof. of Gastroenterology \\ Surgery\& Liver Transplantation Faculty of Medicine Mansoura University; Lecturer of \\ Medical Surgical Nursing, Faculty of Nursing Port Said University
}

\begin{abstract}
Background: Today laparoscopic cholecystectomy (LC) is the gold standard treatment of gall bladder diseases all over the world. Patients undergoing laparoscopic cholecystectomy must be the focus when planning a hospital discharge process by giving them effective practical discharge guidelines that will increase their confidence in managing their care at home, so that, Aim: of the present study was to develop discharge guidelines for patients undergoing laparoscopic cholecystectomy. Design: A descriptive exploratory design was utilized in this study. Setting: The study was conducted at the surgical departments and out patients clinics of GastroenterologyCenter at MansouraUniversity. Sample: A purposive sample of 200 adult patients, from both genders underwent laparoscopic cholecystectomy from the above mentioned setting within 6 months. Tools for data collection: 1) A structure interviewing questionnaire sheet to assess patients' knowledge. 2) An observational checklist to assess patients' practices at pre / postoperative period.3) Health condition assessment sheet to assess patients ' health condition on $1^{\text {st }}$ follow up visit at out Patient's clinic. Results: The mean age of the studied patients was $43.25 \pm 11.01$. More than half $(62.0 \%)$ of studied patients had unsatisfactory level of knowledge as regards laparoscopic cholecystectomy surgery as (pre/post-operative care and discharge instructions). Most (90.5\%) of them had unsatisfactory level of practices as(pre/postoperative practices) added to poor health condition assessment for more than half $(60.0 \%)$ of the studied sample Conclusion: There was a statistical significant relation between patients` total knowledge scores and the total practices scores as regards their socio-demographic characteristics. Moreover, a highly positive correlation was indicated between patients' knowledge \& practices and their health condition assessment. Recommendations: Further research studies are needed to focus on studying factors affecting quality of life for patients undergoing laparoscopic cholecystectomy.
\end{abstract}

Keywords: Laparoscopic cholecystectomy, Patients 'health related knowledge \& practices, Patients` discharge guidelines 


\section{INTRODUCTION}

Gallstone disease is one of the most prevalent gastrointestinal diseases with a substantial burden to health care systems. They are solid calculi formed by precipitation of supersaturated bile composed of cholesterol monohydrate crystals or by black pigment of polymerized calcium bilirubinate (Nunes, 2013 \& Center, 2009). The incidence of gallstones increases with age, fatty female, fertile women and family history or genetics. It was incidentally detected and most patients with cholelithiasis remain asymptomatic for many years. Roughly one tenth with gallstones will develop biliary symptoms within five years after diagnosis. Once symptoms develop, they are unlikely present as an emergency for medical advice (Halldestam et al., 2009).

Biliary colic is the usual presentation of uncomplicated gallstones due to intermittent obstruction of the cystic duct by a stone. Pain is steady, moderate to severe, located in the epigastrium or right upper quadrant of the abdomen, lasts one to five hours and gradually subsides. If pain persists with the onset of fever or high white blood cell count, it should raise suspicion for complications such as acute cholecystitis, gallstone pancreatitis and ascending cholangitis (Wang \& Afdhal, 2010).

Laparoscopic cholecystectomy (LC) method remains the surgical choice for symptomatic and complicated gallstones, with a shorter hospital stay and convalescence period rather than open cholecystectomy method. Percutaneous Cholecystectomy (PC) is an alternative for patients who are critically ill with gallbladder empyema and sepsis (Marks et al., 2011).Laparoscopic cholecystectomy technique is minimal access surgery that has gained a wide acceptance because of high quality of results obtained in various series. It is essentially a safe procedure with low morbidity and mortality rate and decreased overall cost compared to open cholecystectomy (Romanelli et al., 2010).

In the United States, available statistics indicated that, approximately700, 000 cholecystectomy procedures are performed annually and 80 to $90 \%$ of them are candidates for laparoscopic cholecystectomy(Edwards et al., 2010). The incidence of laparoscopic cholecystectomy procedures at gastroenterology center at MansuraUniversity was approximately 796 procedures (According to statistical department at GastroenterologyCenter at MansuraUniversity, 2013).

Laparoscopic cholecystectomy has replaced the open procedure as the treatment option of choice in all instances. It enables to perform a cholecystectomy using a few small incisions in the abdomen and uses a small video camera to magnify the organs of the abdominal cavity. It has been gaining popularity for several reasons : require only small wound, shorter hospitalization , better cosmetics, faster recovery and earlier return to normal activity, less risk of postoperative scarring formation (Marks et al., 2011 and Litwin \& Cahan, 2008 ). The surgeon may have to convert to an open 
procedure because of the presence of scarring, infection, or variant biliary anatomy. Reported conversion rates are around 5\% and are more common with emergent procedures (Kuy et al., 2011).

Complications of laparoscopic cholecystectomy are infrequent but include bleeding, infection and unintended injury to adjacent structures such as: common bile duct or small bowel and may require another surgical procedure to repair it. Bile leakage into the abdomen from the tubular channels leading from the liver to the intestine may rarely occur (Sato et al, 2014 and Kim \& Pickhard, 2011).

Health related knowledge is the degree to which individuals have the capacity to understand basic health information and services needed to make appropriate health decisions, choose a healthy lifestyle, know how to seek medical care and take advantage of preventive measures. It constitutes important constructs that affect prevention of complications and achieving desirable outcomes. Therefore the nurse plays a pivotal role in improving the general wellbeing of patients by addressing these areas in day to day interactions with the patients (Bastable et al., 2011 \& LeinoKilpi et al., 2008).

Recently many studies are defined health related practices as activities and practices performed by the clients to maintain or improve their health, level of wellness, added to minimizing disease and its adverse events. This is a corner stone for establishing the plan of care as well as health education programs, developing policies, administering services and conducting research to satisfy patient's needs, help in coping and be able to modify their health related practices(Mamon \& Steinwachs, 2011).

Discharge information is what patients or those who accompany them expect to receive from health professionals before discharge from the hospital/clinic. This information is given in terms of physical, psychological, educational and social aspects related to different health conditions (Yiu, 2011 and Maloney\& Weiss, 2008).

Discharge planning begins on admission to hospital and continues throughout the hospital stay, such a plan is worthless, however, if the staff are not trained and educated to value its goals and content and to fit the plan to each individual patient's conditions. A discharge instruction must be presented in an easily understood format for these patients to review during and after discharge (Nelson, 2011).

The main focus for the nurse is to empower patients undergoing laparoscopic cholecystectomy with guidelines instructions specific to their pre / postoperative expectations and self-care needs. Lack of information has implications for patients as unmet home care needs and may contribute to poor outcomes and readmission (Armitaged Kavanagh, 2008). 


\section{Significance of the study:}

Studies within the past ten years have determined that, laparoscopic cholecystectomy is the gold standard for treatment of symptomatic gallstone disease(Phillips et al., 2012). The rapid and widespread adoption of laparoscopic cholecystectomy has aroused concern about the safety of the new procedure. LC approach has been gaining popularity for several reasons usually require only small wound, shorter hospitalization, better cosmetics, faster recovery and earlier return to normal activity, less risk of postoperative scarring formation. These laparoscopic (minimally invasive) procedures were proved to have fewer complications than the competing conventional surgical procedures (Chandio et al., 2009).

For most people, an operation is a worrying event, regardless of the procedure or whether they have had surgery before. It is believed that a well-informed patient copes better during the care period and feels less anxiety and pain. One of the cornerstones of enhanced recovery after LC surgery is the provision of adequate information pre and postoperatively and the experience of a safe follow up after hospitalization (Mohn et al., 2009).

Common post discharge complications include: adverse drug events, hospital acquired infections and procedural complications. Many of these complications can be attributed to discharge planning problems as disconnect between clinician information giving and patient understanding, discontinuity between inpatient and outpatient providers and in adequate preparation for patient and family related to lifestyle changes (Yiu, 2011 and Maloney \& Weiss, 2008).

Patients must be the focus when planning a hospital discharge process. Giving effective practical discharge guidelines will increase patients`confidence in managing their care at home, improve health status and make them feel safe and comfortable. This guidelines and information is given in terms of their analgesic regimen, wound care, return to daily living activities, dietary advice, explanation of follow up arrangement and warning signs that needs prompt attention (Phillips et al., 2012).

So, the aim of the current study is to assess the knowledge and practices of patients undergoing laparoscopic cholecystectomy. It is necessary to develop discharge instructions needed for informational and psychological support. It must be presented in an easily understood format for these patients to review during and after discharge.

\section{AIM OF THE STUDY:}

The aim of this study is to develop discharge guidelines for patients undergoing laparoscopic cholecystectomy.

This aim was achieved through: 
- Assessment of knowledge and practices of patients undergoing (LC) regarding (pre/post-operative care and discharge guidelines).

- Developing discharge guidelines based on educational needs of the studied patients.

\section{Research Questions:}

- What is the level of knowledge of patients undergoing laparoscopic cholecystectomy?

- What is the level of practices of patients undergoing laparoscopic cholecystectomy?

- What are the factors affecting knowledge and practices for patients undergoing laparoscopic cholecystectomy?

\section{SUBJECTS AND METHOD:}

The subjects and methods for this study were portrayed under four main designs as follows:

I- Technical design.

II- Operational design.

III- Administrative design.

IV- Statistical design

\section{I-Technical design:}

It included research design, setting, subjects and tools for data collection

\section{Design:}

A descriptive exploratory design was utilized to fulfill the aim of this study.

\section{Setting:}

This study was conducted at the surgical departments and out patients`clinics of Gastroenterology Center at Mansoura University

\section{Subjects:-}

A purposive sample of 200 adult patients from both genders underwent (LC) from the above mentioned settings over a period of 6 months. They were selected based on the sensitive analysis of patients 'number with LC within the year (2013) according to the statistical department which affiliated to the setting with the following criteria:

\section{Inclusion criteria:-}

Conscious adult patients with cholecystitis undergoing laparoscopic cholecystectomy, receiving the same treatment protocol, with non gallstone complications (e.g. obstructive jaundice and pancreatitis) and agree to participate in the study.

\section{Exclusion criteria:-}

Patients who are unable to communicate. 


\section{Tools of the study:-}

Data was collected through the use of the following tools:

\section{Tool (I): A structured interviewing questionnaire sheet}

It was designed by the researcher in simple Arabic language after reviewing of the relevant literatures. It was consisted of three parts as the following:

- Part I: Patients' sociodemographic characteristics including: age, Sex, marital status, level of education, occupation and area of residence.

- Part II: Patients` medical history including series of questions related to past and present medical history as disease onset, manifestations, current medication, presence of chronic diseases and family history.

- part III: Patients` knowledge assessment sheet including closed ended questions to elicit patients` knowledge related to:

$>$ Cholecystitis disease included (8) questions covered (Physiological function of GB, types of GBD, cholecystitis definition, causes, signs and symptoms, complications, diagnosis and methods of treatment).

Cholecystectomy surgery included (6) questions covered (Definition of LC, difference between LC method vs. Open method, steps, benefits, complications and contraindications of LC).

Preoperative preparations included (5)questions covered investigations, diagnostic tests, informed consent, stopping anticoagulant drugs, duration of fasting before surgery, skin preparation ( operative site), clothes and personal items removal, stop smoking, type of anesthesia and source of information or any explanation about operation

Postoperative care included (9) questions covered (position after surgery, type of food and fluid intake after surgery in allowed time, early ambulation, pain management, postoperative exercises as deep breathing, coughing and extremity, added to length of hospital stay).

Patients` discharge guidelines included (10) questions covered steps of wound care, signs and symptoms of wound infection, bathing, precaution of medications intake, diet regimen, follow up visits, situations that need immediate callingor visiting the physician, return to work and daily living activities.

\section{Scoring system:}

The total numbers of questions in the structured questionnaire were 38 questions. Regarding Knowledge scores, correct answer was giving one scores, incorrect or don't know answer was giving zero .The total knowledge scores were 120 scores, the scores of the items were summed up and the total divided by the number of the items.

Theses scores were converted into a percent score and categorized as follows:

$\checkmark \quad$ Satisfactory level for a total grade $\geq 50 \%$ of the maximum score

$\checkmark \quad$ Unsatisfactory level for a total grade $<50 \%$ of the maximum score 


\section{Tool (II): An observational checklist}

It was adapted from (Lewis et al., 2011, Taylor et al., 2011 and Nicol, 2010), developed and modified by the researchers to evaluate studied patients' practices in relation to LC surgery. It was composed of the following:

Preoperative practices included (6) items to be observed at the day before surgery such as: care of operative site, eating, drinking and medication regimen. On the day of surgery such as morning care, cloths, personal items removal and signing informed consent.

Postoperative practices included (7) items to be observed at intermediate postoperative period as positioning, oral fluid \& food intake, pain control measures, care of wound, ambulation \& activities, deep breathing \& coughing and extremity exercises.

\section{Scoring system:}

Scoring of observational checklists was assigned to score according to the number of sub-items of each step in the checklist. Each sub-item was scored as "0" for \{Not Done\} answer and "1" for \{Done\} answer. The scoring system of the check list was computed and the sheet received a final score of 31 scores. The scores of steps were summed up and the total divided by the number of the steps. Theses scores were converted into a percent score and expressed as follows:

$\checkmark$ Satisfactory level for a total grade $\geq 50 \%$ of the maximum score

$\checkmark$ Unsatisfactory level for a total grade $<50 \%$ of the maximum score

\section{Tool (III): Patients` health condition assessment sheet}

This tool was developed by the researcher based on relevant literatures to assess patients 'health conditions on $1^{\text {st }}$ follow up visit to Out Patients' Clinics. It included (6) items to be assessed related to dietary regimen, compliance of medication at home, pain control, wound condition, activity and attendance of follow up visit at time.

\section{Scoring system:}

Scoring of Patient's health condition assessment sheet was assigned to score according to the number of its items. Each item was scored as (zero) for No answer, (1) for yes answer. The total scores of assessment sheet was 6 scores. The scores of the items were summed up and the total divided by the number of the items. Theses scores were converted into a percent score and categorized as follows:

$\checkmark \quad$ Satisfactory level a total grade $\geq 50 \%$ of the maximum score

$\checkmark \quad$ Unsatisfactory level for a total grade $<50 \%$ of the maximum score

$\checkmark$

\section{II: Operational design}

It includes the preparatory phase, face and content validity, pilot study and field work.

\section{A) Preparatory phase}

This phase was conducted through reviewing of the past and current related literatures covering laparoscopic cholecystectomy surgery and discharge information for 
laparoscopic cholecystectomy patients. It was done using available books, articles, internet, periodical and magazines to get acquainted with the research problem and to develop the study tools.

\section{B) Face and content validity}

Face validity was used to reflect the suitability of the questionnaire's items that used as a source for data collection on the studied subjects using common-sense criteria. As well as determine whether the tool measures what it is supposed to measure.

Content validity was used for the modified tools to determine whether the tools cover the aim as well as its relevance and clearance. This stage was developed by a Jury of 9 experts (Assistant professors \& lecturers of medical surgical nursing) from the Faculty of Nursing Ain shams and Port Said University. All recommended modifications were performed.

\section{C) A Pilot study}

A pilot study was carried out after the development of the study tools and before starting the data collection. It was applied on $10 \%$ of the studied patients to test the applicability and clarity of the tools, as well as estimate the time needed to fill in each sheet. Necessary modification was done for the used tools and the final form was developed. Patients included in the pilot study were excluded later from the sample group.

\section{D) Field work:}

$>$ Data collection was started and completed within 6 months from the beginning of February 2015 up to the end of July 2015).

Purpose of the study was simply explained by the researcher to the patients undergoing laparoscopic cholecystectomy who agree to participate in the study before any data collection.

Data were collected on 2 days / week at surgical departments and out patients` clinics of Gastroenterology Center of Mansoura University at morning and afternoon shifts.

Patients were informed to be in contact with the researchers by telephone for any guidance.

Patients` discharge guidelines were developed by the researcher based on deficiency in knowledge and practices of studied patients. It was written in simple Arabic language and consistent with the related literature. Moreover met patients' level of understanding.

The guidelines were presented in theoretical and practical parts. The theoretical part was covered the following items: positioning, wound care, signs and symptoms of wound infection, bathing, medications compliance, return to work and daily living activities, diet regimen, follow up visits, complications and unusual signs that need immediate doctor advice, While the practical part was covered the items as (wound care, hygienic and exercises measures). 


\section{III: Administrative Design:}

An official letter was issued from the Dean of the Faculty of Nursing, Port Said University to the Director of Gastroenterology Center at Mansoura University to obtain the permission before conducting the study.

\section{Ethical considerations:}

All ethical issues were taken into consideration during all phases of the study. The ethical research considerations in this study included the following:

- An informed consent was obtained from patients to participate in the study

- The objectives and aim of the study were explained to the participants before any data collection.

- The researcher was maintained confidentiality and anonymity of the subjects

- The patients had a right to withdraw from the study at any time.

\section{IV: Statistical Design:}

- All collected data were organized, categorized, tabulated, entered and analyzed by using SPSS (Statistical Package for Social Sciences).

- Qualitative data was presented as number and percent. Comparison between groups was done by Chi-Square test.

- Quantitative data was tested for normality by Kolmogrov-Smirnov test.

- Normally distributed data was presented as mean \pm SD. Student t-test was used to compare between two groups. Pearson's correlation coefficient was used to test correlation between variable

凶 Non-significant (NS) $\mathrm{p}>0.05$

冈 Significant $(\mathrm{S}) \mathrm{p} \leq 0.05$

冈 Highly significant (HS) $\mathrm{P}<0.001$

\section{RESULTS:}

Table (1): shows that, the mean age of the study group was $43.25 \pm 11.01$, ranged from 21 to 65 years. Female patients represented more than half $(67.0 \%)$ of the studied sample. About three quarters of them $(71.0 \& 74.0$ respectively) were married and from urban areas. Less than half (44.0\%) of them had intermediate level of education and more than half of them were working $(59.0 \%)$.

Table (2): reveals that, more than three fourths $(78.0 \% \& 80.0 \%$ respectively) of the study sample were complaints from chronic calculus cholecystitis with no chronic diseases. In addition, majority of patients had right side pain, nausea and discomfort (94.0\%, 85.0\%, and $85.0 \%$ respectively). Moreover, more than two thirds of them had sense of fullness, vomiting and flatulence $(79.0 \%, 75.0 \% \& 71 \%$ respectively).As 
regards duration of cholecystitis which titled since months $57.0 \%$ of them were represented.

Table (3): shows that majority of the study sample (82\%) didn't receive explanation about the operation, whereas only $(3.0 \%)$ received explanation from Media (TV, Internet, reading). Findings also showed that, the physician (100\%) was the main preferred source to give advice or knowledge for all the study patients, followed by $(80 \%)$ of the nurses.

Table (4): shows that, more than half $(62.0 \%)$ of the studied patients undergoing LC had unsatisfactory level of knowledge, while only more than one third $38 \%$ of them had satisfactory level of knowledge.

Table (5): shows that, most (90.5\%) of the studied patients undergoing LC had unsatisfactory level of practices and nearly one fifth $(9.5 \%)$ of them had satisfactory level of practices.

Table (6): shows that more than half of $(60.0 \%)$ of the study subjects had unsatisfactory level of total health condition assessment scores, while only (40.0\%) of them had satisfactory level.

Table (7): reveals that, there was a highly statistical significant relation between patients` knowledge (satisfactory and unsatisfactory) as regards their sociodemographic characteristics as: age, residence, occupation, marital status and education, except for the sex non-significant relation was indicated ( $\mathrm{P}$ value $\leq$ 0.001).

Table (8): clarifies that there was a highly statistical significant relation between patients practices (satisfactory and unsatisfactory) as regards their sociodemographic characteristics as: age, occupation, marital status and education, except for the sex and residence non-significant relation was indicated ( $\mathrm{P}$ value $\leq 0.001$ )

Table (9): reveals that, there was a highly positive relation between studied patients total scores of practices and knowledge $(\mathrm{R}=0.870$, with $\mathrm{P}$ value $\leq 0.001)$.

Table (10): Reveals that, there were a highly positive statistical correlation between patient's total knowledge, practices and their total health condition assessment $(\mathrm{r}=$ $0.920,0.829$ with $\mathrm{P}$ value $\leq 0.001$ respectively). 
Table (1): Socio-demographic characteristics of patients undergoing LC (N=200)

\begin{tabular}{|c|c|c|}
\hline Range & Mean \pm SD & Items \\
\hline $21-6$ & $\begin{array}{l}43.25 \pm \\
11.01\end{array}$ & 1. Age \\
\hline$\%$ & No & Items \\
\hline \multicolumn{3}{|l|}{ 2. Gender } \\
\hline 33.0 & 66 & - Male \\
\hline 67.0 & 134 & - Female \\
\hline \multicolumn{3}{|l|}{ 3. Marital Status } \\
\hline 16.0 & 32 & - Single \\
\hline 71.0 & 142 & - Married \\
\hline 6.0 & 12 & - Divorced \\
\hline 7.0 & 14 & - Widowed \\
\hline \multicolumn{3}{|l|}{ 4. Education } \\
\hline 26.0 & 52 & - Illiterate \\
\hline 17.0 & 34 & - Read and write \\
\hline 44.0 & 88 & - Intermediate \\
\hline 13.0 & 26 & - University \\
\hline \multicolumn{3}{|l|}{ 5. Occupation } \\
\hline 59.0 & 118 & - Working \\
\hline 41.0 & 82 & - Not working \\
\hline \multicolumn{3}{|l|}{ 6. Residence } \\
\hline 26.0 & 52 & - Rural \\
\hline 74.0 & 148 & - Urban \\
\hline
\end{tabular}

Table (2): Medical history of Patients undergoing LC

\begin{tabular}{|c|c|c|}
\hline \multicolumn{2}{|c|}{$(\mathbf{n}=\mathbf{2 0 0})$} & \multirow{2}{*}{ Patient's medical history } \\
\hline$\%$ & No & \\
\hline \multicolumn{3}{|c|}{ \& Diagnosis (Indication Of Surgery) } \\
\hline 78 & 156 & - Chronic calculus cholecystitis \\
\hline 19 & 38 & - Acute calculus cholecystitis \\
\hline 3 & 6 & - Acute a calculus cholecystitis \\
\hline \multicolumn{3}{|c|}{ \# Duration of cholecystitis } \\
\hline 25. & 50 & - $\quad$ Since days \\
\hline 57. & 114 & - $\quad$ Since months \\
\hline 18. & 36 & - Since years \\
\hline \multicolumn{3}{|c|}{ \# Signs \& symptoms of cholecystitis } \\
\hline 94. & 188 & - Right Sided Pain \\
\hline 85. & 170 & - Nausea \\
\hline 75. & 150 & - $\quad$ Vomiting \\
\hline 79. & 158 & - Sense of Fullness \\
\hline 71. & 142 & - $\quad$ Flatulence \\
\hline 48. & 96 & - $\quad$ Yellowish skin \\
\hline 85. & 170 & - Discomfort \\
\hline 34. & 68 & - $\quad$ Fever \\
\hline
\end{tabular}

\# More than one answer was selected 
Table (3): Presentation of information sources about surgery among the studied patients

\begin{tabular}{|c|c|c|}
\hline \multicolumn{2}{|c|}{$\begin{array}{l}\text { Studied patients } \\
\qquad(\mathrm{n}=\mathbf{2 0 0})\end{array}$} & \multirow[t]{2}{*}{ Information sources } \\
\hline$\%$ & No & \\
\hline $\begin{array}{l}18.0 \\
82.0\end{array}$ & $\begin{array}{c}36 \\
164\end{array}$ & $\begin{array}{l}\text { 1. Obtaining explanation about surgery } \\
\text { - Yes } \\
\text { - } \mathrm{No}\end{array}$ \\
\hline $\begin{array}{c}10.0 \\
12.0 \\
18.0 \\
3.0\end{array}$ & $\begin{array}{c}20 \\
24 \\
36 \\
6\end{array}$ & $\begin{array}{l}\text { 2. \# Source of knowledge about surgery } \\
\text { - Health care provider (physician, nurse.) } \\
\text { - } \text { Family ,friends, neighbors } \\
\text { - } \text { Other patient } \\
\text { - Media (TV, Internet, reading......) }\end{array}$ \\
\hline $\begin{array}{l}100.0 \\
80.0 \\
12.0\end{array}$ & $\begin{array}{l}200 \\
160 \\
24\end{array}$ & $\begin{array}{l}\text { 3. \# Best source to give advice or knowledge } \\
\text { - physician } \\
\text { - } \text { nurse } \\
\text { - Family, friends and neighbors }\end{array}$ \\
\hline
\end{tabular}

\# More than one answer was selected

Table (4): Presentation of total knowledge scores among the studied patients

\begin{tabular}{|c|c|c|c|c|}
\hline \multirow{2}{*}{ Variables } & \multicolumn{2}{|c|}{ Satisfactory } & \multicolumn{2}{c|}{ Un Satisfactory } \\
\hline \multirow{2}{*}{ Total knowledge scores } & No & $\%$ & No & $\%$ \\
\cline { 2 - 5 } & 76 & 38.0 & 124 & 62.0 \\
\hline
\end{tabular}

Table (5): Presentation of total practices scores among the studied patients

\begin{tabular}{|c|c|c|c|c|}
\hline \multirow{2}{*}{ Variables } & \multicolumn{2}{|c|}{$\begin{array}{c}\text { (Satisfactory) } \\
\text { Done }\end{array}$} & \multicolumn{2}{c|}{$\begin{array}{c}\text { (Un Satisfactory) } \\
\text { Not done }\end{array}$} \\
\hline \multirow{2}{*}{ Total practices scores } & No & \% & No & $\%$ \\
\cline { 2 - 5 } & 19 & 9.5 & 181 & 90.5 \\
\hline
\end{tabular}


Table (6): Presentation of total health condition assessment scores among the studied patients

\begin{tabular}{|c|c|c|c|c|}
\hline \multirow{2}{*}{ Variables } & \multicolumn{2}{|c|}{ Satisfactory } & \multicolumn{2}{c|}{ Un Satisfactory } \\
\hline \multirow{2}{*}{$\begin{array}{c}\text { Total health condition } \\
\text { assessment scores }\end{array}$} & 80 & 40.0 & 120 & 60.0 \\
\cline { 2 - 5 } & No & $\%$ & No & $\%$ \\
\hline
\end{tabular}

Table (7): Relation between total scores of knowledge among the studied patients as regards their socio-demographic characteristics

\begin{tabular}{|c|c|c|c|c|}
\hline \multirow{2}{*}{ Items } & Satisfactory & Un satisfactory & \multirow{2}{*}{$\mathbf{T}$} & \multirow{2}{*}{$\begin{array}{c}P . \\
\text { value }\end{array}$} \\
\hline & $\mathrm{N}=76$ & $\mathrm{~N}=124$ & & \\
\hline Age $($ Mean \pm SD $)$ & $\begin{array}{c}39.46 \pm \\
11.48\end{array}$ & $45.57 \pm 10.07$ & 3.867 & $\begin{array}{c}0.001^{*} \\
<\end{array}$ \\
\hline Items & $\begin{array}{c}\text { Satisfactory } \\
\%\end{array}$ & $\begin{array}{c}\text { Un satisfactory } \\
\%\end{array}$ & $\mathbf{X}^{2}$ & $\begin{array}{c}P . \\
\text { value }\end{array}$ \\
\hline $\begin{array}{l}\text { Sex } \\
\quad \text { Male } \\
\text { - Female }\end{array}$ & $\begin{array}{l}33.3 \\
40.3\end{array}$ & $\begin{array}{l}66.7 \\
59.7\end{array}$ & 0.911 & 0.340 \\
\hline $\begin{array}{l}\text { Marital status: } \\
\text { - Single } \\
\text { - Married } \\
\text { - Divorced } \\
\text { - Widow }\end{array}$ & $\begin{array}{c}87.5 \\
16.9 \\
100.0 \\
87.5\end{array}$ & $\begin{array}{c}12.5 \\
83.1 \\
0.0 \\
14.3\end{array}$ & 93.218 & $\begin{array}{c}0.001^{*} \\
<\end{array}$ \\
\hline $\begin{array}{l}\text { Educational level } \\
\text { - Illiterate } \\
\text { - Read and write } \\
\text { - Secondary } \\
\text { - University }\end{array}$ & $\begin{array}{c}0.0 \\
2.9 \\
55.7 \\
100.0\end{array}$ & $\begin{array}{c}100.0 \\
97.1 \\
44.3 \\
0.0\end{array}$ & 103.708 & $\begin{array}{c}0.001^{*} \\
<\end{array}$ \\
\hline $\begin{array}{l}\text { Occupation } \\
\text { - Working } \\
\text { - Not working }\end{array}$ & $\begin{array}{l}55.9 \\
12.2\end{array}$ & $\begin{array}{l}44.1 \\
87.8\end{array}$ & 39.282 & $\begin{array}{c}0.001 * \\
<\end{array}$ \\
\hline $\begin{array}{l}\text { Residence } \\
\text { - Urban } \\
\text { - Rural }\end{array}$ & $\begin{array}{l}45.9 \\
15.4\end{array}$ & $\begin{array}{l}54.1 \\
84.6\end{array}$ & 15.255 & $\begin{array}{c}0.001 * \\
<\end{array}$ \\
\hline
\end{tabular}


Table (8): Relation between total scores of practices among the studied patients as regards their socio-demographic characteristics

\begin{tabular}{|c|c|c|c|c|}
\hline \multirow[t]{2}{*}{ Items } & $\begin{array}{c}\text { Done } \\
\text { ( Satisfactory ) }\end{array}$ & $\begin{array}{c}\text { Not done } \\
\text { (Unsatisfactory ) }\end{array}$ & \multirow[t]{2}{*}{$\mathbf{T}$} & \multirow[t]{2}{*}{ P. value } \\
\hline & $\mathbf{N}=19$ & $\mathrm{~N}=181$ & & \\
\hline Age $($ Mean \pm SD $)$ & $29.74 \pm 5.45$ & $44.67 \pm 10.47$ & 10.145 & $<0.001^{*}$ \\
\hline Items & $\begin{array}{c}\text { Done } \\
\%\end{array}$ & $\begin{array}{c}\text { Not done } \\
\%\end{array}$ & $\mathbf{X}^{2}$ & P. value \\
\hline $\begin{array}{ll}\text { Sex } & \\
\text { - } & \text { Male } \\
\text { - } & \text { Female }\end{array}$ & $\begin{array}{c}4.5 \\
11.9\end{array}$ & $\begin{array}{l}95.5 \\
88.1\end{array}$ & 2.813 & 0.094 \\
\hline $\begin{array}{l}\text { Marital status: } \\
\text { - Single } \\
\text { - } \text { Married } \\
\text { - Divorced } \\
\text { - Widow }\end{array}$ & $\begin{array}{c}15.6 \\
5.6 \\
41.7 \\
7.1\end{array}$ & $\begin{array}{l}84.4 \\
94.4 \\
58.3 \\
92.9\end{array}$ & 18.397 & $<0.001 *$ \\
\hline $\begin{array}{l}\text { Educational level } \\
\text { - Illiterate } \\
\text { - Read and write } \\
\text { - Secondary } \\
\text { - University }\end{array}$ & $\begin{array}{c}0.0 \\
0.0 \\
12.5 \\
30.8\end{array}$ & $\begin{array}{c}100.0 \\
100.0 \\
87.5 \\
69.2\end{array}$ & 23.629 & $<0.001^{*}$ \\
\hline $\begin{array}{l}\text { Occupation } \\
\text { - Working } \\
\text { - } \text { Not working } \\
\end{array}$ & $\begin{array}{c}14.4 \\
2.4\end{array}$ & $\begin{array}{l}85.6 \\
97.6\end{array}$ & 8.060 & $0.005^{*}$ \\
\hline $\begin{array}{c}\text { Residence } \\
\text { - Urban } \\
\text { - Rural }\end{array}$ & $\begin{array}{c}8.8 \\
11.5\end{array}$ & $\begin{array}{l}91.2 \\
88.5\end{array}$ & 0.340 & 0.560 \\
\hline
\end{tabular}

Table (9): Correlation between total knowledge and practices scores among the studied patients

\begin{tabular}{|c|c|c|}
\hline \multirow{2}{*}{ Variables } & \multicolumn{2}{|c|}{ Total knowledge scores } \\
\cline { 2 - 3 } & $\mathbf{R}$ & $\mathbf{P}$ value \\
\hline Total practices scores & $\mathbf{0 . 8 7 0}$ & $<0.001 *$ \\
\hline
\end{tabular}

$\mathrm{R}=$ Pearson correlation $\quad *$ Highly Significance $\leq 0.001$ 
Table (10): Correlation between patient's knowledge, practices and their total health condition assessment

\begin{tabular}{|c|c|c|}
\hline \multirow{2}{*}{ Variable } & \multicolumn{2}{|c|}{$\begin{array}{c}\text { Total health condition assessment } \\
\text { Score }\end{array}$} \\
\cline { 2 - 3 } & $\mathbf{R}$ & $\mathbf{P}$ \\
\hline Total knowledge Score & 0.920 & $0.001 * *<$ \\
Total practices Score & 0.829 & $0.001 * *<$ \\
\cline { 2 - 3 } & & \\
\hline
\end{tabular}

$\mathrm{r}=$ Pearson correlation

** Highly Significance $\leq 0.001$

\section{DISCUSSION:}

Today with increasing the current trend for 'key hole' surgery, laparoscopic cholecystectomy (LC) is considered the gold standard treatment of gall bladder diseases all over the world. Patients undergoing LC are being discharged almost immediately following surgery or soon after they are able to mobilize. Consequently, health professionals should make a significant contribution through the provision of discharge information to patients prior to discharge home that will increase their confidence in managing their care at home (Hedges et al., 2009).

This study aimed to develop discharge guidelines for patients undergoing laparoscopic cholecystectomy through

Assessment of knowledge and practices of patients undergoing laparoscopic cholecystectomy

Develop discharge guidelines based on educational needs of the studied patients.

Discussion of the present study is categorized into the following parts:

Part I: Sociodemographic characteristics of the studied patients.

Part II: Level of patients` knowledge

Part III: Level of patients` practices

Part IV: Patients` health condition assessment

Part V: Relations and correlation between variables under study.

\section{Characteristics of the studied patients:}

As regards patients' age, the current study has shown that mean age of them was 43.25 \pm 11.01 ranged from 21 to 65 years. This finding was supported by Nabil et al. (2009) who reported that, the mean age of patients undergoing laparoscopic cholecystectomy was $44.5 \pm 11.8$ years and their age ranged from 23-64 years. In addition Tao et al. (2012) reported that, the frequency of gallbladder stones increases with age, escalating markedly after age 40 to become 4 to 10 times more likely in older individuals .

In relation to studied patients`gender, as shown female were represent a higher percentage. This finding was supported by Sinton et al. (2012) \& Rosen et al. (2010) who stated that, majority of the studied patients were females and form stones due to 
the underlying mechanism of female sex hormones, pregnancy; use oral contraceptive and estrogen replacement therapy. Variations in estrogen causing increased cholesterol secretion and progesterone causing bile stasis.

Concerning educational level, occupation and residence, the studied sample showed that minority of them had completed the university degree and more than half of them were from urban areas and working. These results were in accordance with Barthelssona, Norberg \& Nordström (2009) who found that, less than one fifth of the study subjects had university education and majority of them were from urban areas working.

In relation to medical history of the studied patients, it was found that more than half of them were complaint from symptomatic cholecystitis since months and diagnosed as chronic calculous cholecystitis then undergo LC procedure. Gurusamy et al. (2013) reported that LC should be recommended to all patients who appropriate operative candidates. Zhu et al. (2012) emphasized that surgery for acute cholecystitis could be time critical and early laparoscopic cholecystectomy reflected the low rates of complications, conversation, morbidity rate and a shorter hospital stay.

On the same line, as regards disease manifestations, majority of them had right sided pain, nausea and discomfort followed by sense of fullness, flatulence, fever and jaundice. These findings were supported by Schirmer et al. (2008) who reported that biliary colic is the primary presenting symptom in $80 \%$ of people with symptomatic gallstones and occurs after eating greasy or fatty foods that leads to nausea or vomiting. Indigestion, belching, bloating and fatty food intolerance are thought to be typical symptoms of gallstones

\section{Level of Patients` Knowledge}

The study results revealed that, more than half of the studied patients undergoing LC had unsatisfactory level of knowledge related to different area about care of patients undergoing LC, while only more than one third of them had satisfactory level of knowledge.

Concerning patients` knowledge about preoperative preparations, the current study revealed that majority of the studied subjects had unsatisfactory level of knowledge about preparations that should follow before surgery. This result may be due to work overload of health team which leads to lack of patients' information about preoperative instructions. The researcher observed that the nurses are either too busy with administrative work or routine work. This result was supported by Davis \& Petersen (2011) and Smith et al. (2011) who reported that, the nurses perform only the professional activities such as taking vital signs, giving treatment, but they have a lack of time to give any knowledge about the patients` medical conditions or teaching how to prepare themselves for the surgery. 
On the same line, majority of the studied subjects didn't know about the written consent. This may be due to that consent form was signed on the morning of surgery so they were not aware about it before this time. The written consent should be taken at least one day before the surgery in order to raise patient's learning about the procedure in more detail. This result was supported by Berry et al. (2011) who reported that the timing of obtaining informed consent is very important and the patient must have time to receive sufficient information to make a decision about a planned surgical procedure.

Considering knowledge about wound care, majority of patients didn't know either steps of wound care or signs and symptoms of wound infection. These findings goes in the same line with Henderson \& Zernike (2008) who found that, over half of the patients did not receive information on wound care when in hospital and they accessed a health facility after discharge because of a wound related problem that they did not know how to care for their wound. These problems included wound ooze or infection. In addition Harlan et al. (2010) stated that patients felt dissatisfied because of inadequate advice given regarding suture management.

In relation to knowledge about diet regimen, majority of the studied subjects didn't know what should be eaten after gallbladder removal. These findings were in agreement with Yang (2009) who mentioned that patients have great needs to understand their diet plan after surgery. Gaby (2009) reported that, patients after their gall bladder removed, may experience a problem of diarrhea, so the nurse should inform the patient to increase fiber in diet, limiting foods that worsen diarrhea as caffeine, dairy products and very sweet foods. Also avoid high fat foods as fried foods and foods made with lard or butter.

Concerning patients`source of their information about the operation, the present study revealed that, information source was through other patients and family and this indicated that the advice was taken from unreliable source, so they had inadequate information about their health condition or treatment. This results were supported by Shoeb, et al. (2012) \& Abdul- star et al. (2011) who stressed upon, the health care professionals should present themselves as a primary source of information for patients and they should provide them with evidence based knowledge will improve their compliance toward their treatment and prevent further postoperative complication.

The study results revealed that, most patients prefer to get their instructions from physicians followed by nurses. However, this could be one of the reasons for the remarkable percentages of dissatisfaction on all the knowledge items because health professionals do not have available time to spend giving clear, meaningful information to patients. This concept has been explained by Ul Haq et al. (2013) who stated that primary reason of lack of knowledge is linked to poor communication between health care professional and the patient which lead to lack of information about their disease consequence and its management. In addition, Mohamed (2013) found that, two thirds 
of patients in his study results prefer to get their instructions from the most senior person in the treating team as physicians, followed by one fourth of them prefer nurses to get their information.

\section{Level of Patients' practices:}

As regards to patients 'practices, findings of the present study revealed that most of the studied patients had unsatisfactory level of practices. This result may be due to lack of clinical procedures and unavailability of instruction resources about treatment.

The present study revealed that, minority of the patients done the practices regarding breathing and coughing exercises or extremity exercises after surgery. These result ascertained that the patients didn't receive any instructions about how to demonstrate these exercises or know the importance of these exercises. All patients need to learn how to practice breathing, coughing, leg and foot exercises before surgery. These findings were in agreement with Shaw (2013) who reported that diaphragmatic (abdominal) breathing and coughing exercises should be taught to the client who undergoes general anasethesia to prevent developing pulmonary complications, such as atelectasis or pneumonia. Kulaylat and Dayton (2015).

Stressed upon, the nurse should educate the patient how to perform leg, ankle, and foot exercises every 1 to 2 hours while awake to maintain good blood circulation, depending on clients' ambulatory status, physician's preference and institutional protocol.

\section{Patients` health condition assessment:}

As regards to patients` health condition assessment on $1^{\text {St }}$ follow -up visit, the study results revealed that more than half of the studied patients had unsatisfactory level. They experienced problems with their wound such as: wound ooze, breakdown, infection and pain associated with their site of the incision that required further management regarding the taking of analgesics. These problems attributed to a lack of receiving discharge information about wound care or on how to manage their pain at home. This results were agreed by Willirad (2010) who found that, many patients in his study did not receive information on management of pain and wound care experienced problems and/or concerns after discharge that required to make a nonroutine visit to a health facility. Harlan et al. (2010) suggested that if informations given to the patients are sufficient, then they should not need to access a health facility if everything is progressing normally.

\section{Relation and correlations between study variables:}

As regards to relation between socio-demographic characteristics of studied subjects and knowledge scores, results obtained showed that age of them had a significant influence on knowledge and practices. Moreover, younger age had better knowledge and practices than older age. These results were in consistent with Yung et al. (2008) who found that, younger patients and those with a better education had higher 
expectations of their own involvement and tended to be less reluctant to question decisions made about their own health care. Bijoy et al. (2012) \& Hasnain and sheikh (2009) found that female patients had a slightly poorer level of knowledge than men.

Regarding educational level, the present study showed that the patient with a higher education was more knowledgeable than low educated because. This finding was in accordance with the study conducted by Saadia et al. (2010) \& Kamel et al. (2008) who reported that, low educational level is associated with poor knowledge as it limits the access to information resources mainly due to difficulty in reading, writing or understanding the disease.

In relation to patients` knowledge and area of residence, the present study showed significant relation and there was a lack of knowledge among patients in the rural areas. This may be related to many people don't seek early diagnosis and treatment in rural areas. The health seeking behavior was better in urban communities and the reasons for this could possibly be ease of access to the health care facilities and better knowledge about the disease. These findings were supported by Mushtaq et al. (2011) and Maloney \& Weiss (2008).

As regards correlation between level of knowledge and practices among the studied patients, the present study revealed a highly significant correlation. It indicated that adequate knowledge can lead to a positive attitude resulting in good practices, this explanation illustrated by Mitchie et al. (2008) who found that the positive correlations are explainable by the theory of reasoned actions; persons 'intention to a specific behavior is a function of their attitude towards that behavior. Furthermore, $\boldsymbol{U l}$ Haq et al. (2013) concluded that correct knowledge is a power resource for positive attitude which brings about a positive change in patients` practices.

Considering correlation between level of knowledge, practices and health condition assessment among the studied patients, the present study revealed a highly positive correlation between patients' knowledge, practices and their health condition assessment. It indicated that if the patients had sufficient information regarding their disease, its consequence and the treatment options, they will be able actively to participate in the process of recovery after surgery. This findings were agreed with Sahlsten et al. (2010) and Henderson \& Zernike (2008) who stated that, patients who are knowledgeable and possess accurate and complete information about their health condition are better to understand and follow physicians' instructions to obtain the best and most successful health outcomes.

\section{CONCLUSION:}

In the light of the current study, it can be concluded that, more than half of the studied patients undergoing laparoscopic cholecystectomy had unsatisfactory level of total knowledge scores as regards laparoscopic cholecystectomy surgery (pre/post-operative care and discharge instructions), Most of them had unsatisfactory level of total practices scores regarding pre/post-operative practices added to poor health condition assessment for more than half of the studied sample. There was a statistical significant 
relation between patients' total knowledge scores and total practices scores as regards their sociodemographic characteristics. Moreover, a highly positive correlation was indicated between patients' knowledge and practices as regards their health condition assessment.

\section{RECOMMENDATION:}

In the light of the findings of the present study, the following recommendations are suggested:

- Distribution of a simple illustrated and comprehensive Arabic booklet for patients undergoing laparoscopic cholecystectomy surgery including all information about cholecystectomy surgery, pre/post-operative preparations and discharge instructions that should follow.

- Continuous health needs assessment for patients undergoing laparoscopic cholecystectomy.

- Assessment of the factors affecting quality of life for patients undergoing laparoscopic cholecystectomy.

- Conducting an orientation programs for patients undergoing laparoscopic cholecystectomy to increase their level of knowledge and practices.

-Educational programs should be provided for nurses to update their knowledge about care needed for Patients undergoing laparoscopic cholecystectomy surgery

\section{REFERENCES:}

Abdul-sater, L., Henry, M. \& Majdan, A. (2011): what thyroidectomy patients really concerned about? August 17; 7(76); 78-83.

Armitage, S. \& Kavanagh, K. (2008): Hospital nurses' perceptions of discharge planning for medical patients. Aust J AdvNurs 14: 16-23

Barthelssona, C., Norberg, A. \& Nordstrom, G. (2009): Longitudinal changes in health and symptoms following Laparoscopic Cholecystectomy, Ambulatory Surgery J; 8 (15): 4 - 6.

Bastable, S., Grambet, P., Jacobs, K. \& Sopczyk, D. (2011): Health professionals as educator: Principles of teaching and learning. Bartlett Learning, LLC; 9(56): 876-9.

Berry, M., Unwin, J., Ross, G., Peacock, E. \& Juma, A. (2011): A comparison of the views of patients and medical staff in relation to the process of informed consent. Ann R Coll Surg Engl; 89(4): 368-73

Bjjoy, c., Feba, A., and Vikas, R. (2012): knowledge assessment and patient counseling on diabetic foot care. Indian J of pharmacy practice; 5(2): 11-15.

Center, S. (2009): Diseases of the gallbladder and biliary tree. North Am J. May: 39(3): 543- 8 . 
Chandio, A., Timmons, S. \& Majeed, A. (2009): Factors influencing the successful completion of laparoscopic cholecystectomy. JSLS 13(9): 581-6.

Davis, B. \& Petersen, J. (2011): Examining patient education needs related to lung cancer treatment; age - related analysis in 9 nursing sensitive patient outcomes. Available at: http://www.cancer facts.com.

Edwards, C., Bradshaw, A. \& Ahearne, P. (2010): Single incision laparoscopic cholecystectomy is feasible: initial experience with 80 cases. Surg Endosc; 24 (9): 2241- 47.

Gaby, A. (2009): Nutritional approaches to prevention and treatment of gallstones. Altern Med Rev; 14: 258- 67.

Gurusamy, S., Davidson, C. \& Gluud, C. (2013): Early versus delayed laparoscopic cholecystectomy for people with acute cholecystitis. Cochrane Database Syst Rev. Jun; 30(6): $345-7$.

Halldestam, I., Kullman, E. \& Borch, K. (2009): Incidence of gallstone disease in a general population sample. Br J Surg Nov: 96(11): 1315-9.

Harlan, G., Nkoy, F., Srivastava, R., Lattin, G. \& Wolfe, D. (2010): Improving transitions of care at hospital discharge implications for pediatric hospitalists and primary care providers. J Healthc Qual; 32(5): 51-60.

Hasnain, S. \& Sheikh, N. (2009): knowledge and practices regarding foot care in diabetic patient's clinic in Jinnah hospital. Lahore J Park Med Assoc; 59(10): 687-90.

Hedges, G., Grimmer, K., Moss, J. \& Falco, J. (2009): Performance indicators for discharge planning after surery: A focused review of the literature. Aust $\mathbf{J}$ Adv Nurs: 20- 8 .

Henderson, A. \& Zernike, $\boldsymbol{W}$. (2008): A study of the impact of discharge information for surgical patients. J Adv Nurs; 35(3): 435-41.

Kamel, N., Badawy, Y. \& EL Zeiny, N. (2008): Socio demographic determinates of management behavior of diabetic patients: 5(5):974-83

Kim, D. \& Pickhard, P. (2011): Diagnostic imaging procedures in gastroenterology. In: Goldman L, Schafter AI, eds. Cecil Medicine. 24th ed. Philadelphia, Pa: Saunders Elsevier.

Kulaylat, M. \& Dayton, M. (2015): Surgical complications. In: Townsend CM, Beauchamp RD, and Evers BM, eds. Sabiston Textbook of Surgery. 19th ed. Philadelphia, PA: Elsevier Saunders. 
Kuy, S., Sosa, J., Roman, S., Desai, R. \& Rosenthal, R. (2011): outcome of Single incision laparoscopic cholecystectomy in American patient Am J surg; 201(6): 78996.

Leino-Kilpi, H., Iire, L., Suominen, T., Vuorenïeimo, J. and Valimaki, M. (2008): Client and information: a literature review. Journal of Clinical Nursing; 2(8): 331- 40.

Lewis, S., Heitkemper, M. \& Dirksen, S. (2011): Medical-Surgical Nursing: Assessment and Management of Clinical Problems, $8^{\text {th }}$ ed., 343-8.Litwin, D. \& Cahan, M. (2008): Laparoscopic cholecystectomy. Surg Clin North Am. Dec. 88(6): 1295- 8.

Maloney, L. \& Weiss, M. (2008): Patients' perceptions of hospital discharge informational content. Clin Nursing Res; 17(3): 200-9.

Mamon, J. \& Steinwachs, D. (2011): Impact of hospital discharge planning on meeting patient needs after returning home. Journal of Health Services Research; 27(5): 155-9.

Marks, J.,Tacchino,R. \& Roberts, K. (2011): Prospective randomized controlled trial of traditional laparoscopic cholecystectomy versus single incision laparoscopic cholecystectomy: report of preliminary data. Am J Surg; 20 (3): 369-72.

Mitchie, S., Johnson, M., Francis, J., Hardeman, W., \&Eccles, M. (2008): From theory to intervention: Mapping theoretically derived behavioural determinanants to behaviour change techniques. Applied Psychology: An International Review, 57(4): 660-680.

Mushtaq, M., Hussain, A. \& Abdulla, s. (2011): Urban -Rural inequities in knowledge, attitudes and practices regarding tuberculosis in two districts of Pakistan's Punjab province international equity in health $\mathrm{J}:$ 10(8), Available at http://www.equityhealthj.com/content/10/1/8

Mohamed, M. (2013): Patient perceptions regarding information given on hospital discharge in Al madinah Al munawwarah, Kingdom of Saudi Arabia. Journal of Taibah University Medical Sciences; 8(2), 105-9.

Mohn, A., Bernardshaw, S., Ristesund, S., Hovde Hansen, P. \& Rokke, O. (2009): Enhanced recovery after laparoscopic cholecystectomy surgery. Results from a prospective observational two-centre study. Scandinavian Journal of Surgery: 98, (3) 155- 9 .

Nabil, A., Mohamed, A., Khalid, E. \& Ahmed, M. (2009): Pre-Operative Prediction of Difficult Laparoscopic Cholecystectomy Using Clinical and Ultrasonographic Parameters. Journal of the Medical Research Institute JMRI; 27(3): 102-7.

Nelson, C. (2011): Patient satisfaction surveys: An opportunity for total quality improvement. Health Services Administration J; 35(8): 409 -17. 
Nicol, M. (2010): Essential Nursing Skills, Mosby Company, St., Louis, 366.

Nunes, D. (2013): Dissolution therapy for the treatment of gallstones. Up Avaliable At $\{\{$ www.uptodate.com/contents/dissolution-therapy-for-the-treatment-of-gallstones. Accessed February 4 .

Phillips, M., Marks, J. \& Roberts, K. (2012): Intermediate results of a prospective randomized controlled trial of traditional four-port laparoscopic cholecystectomy versus single -incision laparoscopic cholecystectomy. Surg Endosc; 26 (5): 1296-303.

Romanelli, J., Roshek, T., Lynn, D. \& Earle, D. (2010): Single port laparoscopic cholecystectomy: initial experience. Surg Endosc; 24: 1374-1379.

Rosén, H., Bergh, I., Lundman, B. \& Mårtensson, L. (2010): Patients' experiences and perceived causes of persisting discomfort following day surgery, licensee BioMed Central Ltd. BMC Nursing, (9): 16.

Sato, N., Shibao, K., Mori, Y. \& Higure, A. (2014): Postoperative complications following single-incision LC: a retrospective analysis in 360 consecutive patients. Surg Endosc. Jul 23.

Saadia, Z., Rushdi, S., Sheeha, M., Hassan, S. \& Rajab, M. (2010): A study of knowledge, attitude and practices of Saudi women towards diabetes mellitus: a KAP study in Al-Qassim region. Internet J Health; 11 (2): 223-27.

Sahlsten, M., Larsson, I., Sjostrom, B. \& Plos, K. (2010): Nurse Strategies for optimizing patient participation in nursing care. Scandinavian Journal of Caring Science; 23 (3): 490- 7.

Schirmer, B., Winters, K. \& Edlich, R. (2008): Cholelithiasis and cholecystitis. J Long Term Eff Med Implants.15 (3): 329-38 .

Shaw, B. (2013): Review of the effectiveness of various modes of breathing training in asthma management. African Journal for Physical, Health Education, Recreation and Dance. November (Supplement 1): 168- 79. Retrieved 2015-02-11

Shoeb, M., Kee, C. \& Johnson, A. (2012): “Can we just stop and talk?" Patients value verbal communication about discharge care plans. J Hosp Med 2012, http://dx.doi.org/10.1002/jhm.1937.

Smith, I., Kranke, P. \& Murat, I. (2011): Preoperative fasting in adults and children: guidelines from the European Society of Anaesthesiology. Eur J Anaesthesiol; 28: 556-69.

Statistical Department (2013): Gastroenterology at Mansour University. 
Stinton, L., Myers, R. \& Shaffer, E. (2012): Epidemiology of gallbladder disease: Cholelithiasis and cancer. Gut LiverJ: 6 (2): 172-87.

Tao, L., Xue, $Q$. \& Wufg, $Q$. (2012): Prevalence of and risk factors for biliary stones and gallbladder polyps in a large sample population. HPB J; 14(6): 373-81.

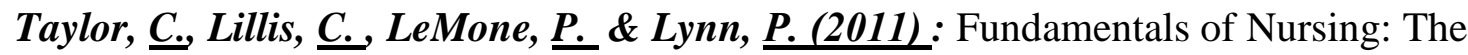
Art and Science of Nursing Care, $7^{\text {th }}$ ed., Lippincott Williams \& Wilkins.

Ul haq, N, Azmi,M, Saleem,F, Maryam Farooqui, M. \& Aljadhey, H. (2013): across sectional assessment of knowledge, attitude and practice among Hepatitis B patients in Quetta, Pakistan's BMC public health; 13-448. Available at http://www.bio med central.com/1471-2458/13/448.

Wang, D. \& Afdhal, N. (2010): Gallstone disease. In: Friedman LS, Sleisenger and Fordtran's Gastrointestinal and liver disease.9th Ed. Philadelphia, PA: Saunders Elsevier .

Williard, M. (2010): Post-discharge call programs: improving satisfaction and safety. Med J of Qual Healthcare, 12 (5): 32-7.

Yang, Z. (2009): Laparoscopic Cholecystectomy in patients with the investigation and analysis of health needs, India - surgical sutures, / article / 28359 overview, 16: (34).

Yiu, H. (2011): Information needs of Chinese surgical patients on discharge: a comparison of patients' and nurses' perceptions. J Adv Nurs; 67(5): 1041-8.

Yung, C., Tse,S., Chan, K., Chow, C., Yau, C. \& Chan, T. (2008): Age-related decline in the knowledge of diabetes mellitus and hypoglycaemic symptoms in noninsulin-dependent diabetes patients in Hong Kong.Age and Ageing, 327- 32.

Zhu, B., Zhang, Z., Wang, Y., Gong, K., Lu, Y. \& Zhang, N. (2012): Comparison of laparoscopic cholecystectomy for acute cholecystitis within and beyond $72 \mathrm{~h}$ of symptom onset during emergency admissions. World J Surg; 36(11): 2654-8. 


\section{تطوير إرشـادات الخروج للمرضي الخـاضعين لإستئصال الحويصلة المرارية}

\section{بالـمنظـار الجراحي}

أسـماءعبد الجليل قدوس ،د. سعـاد محمود حجازى ، د. طارق صلاح الحسيني ، د. بهية جلال عبد الرازق

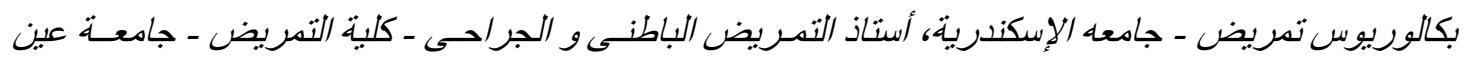
شمس ، أستاذ مساعد جراحة الجهاز الهضمي وزر/عة الكبد ـ كلبة الطب - جامعـة المنصورة ، مدرس التصريض الباطني والجر/حي ـ كلبة التمريض - جامعسة بورسعبي

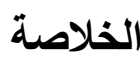

لقد أصبح الأن استئصلال الحويصلة المرارية بالمنظار الجراحى هو الإجراء الجراحي الأكثر انتشارا و المفضل في علاج أمر اض الحويصلة المرارية في جميع أنحاء العالم. يجب النظر لحاجة المرضى الخاضعين لإستئصال

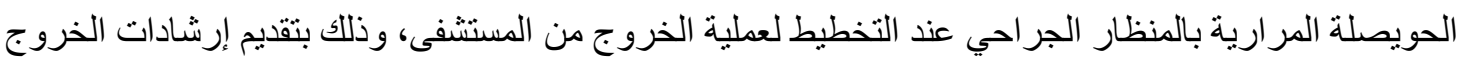
الفعالة والتي تؤدي الي زيادة ثقتهم في تحقيق مسنوي مناسب من ممارسة الرعاية الذاتية في المنزل ـهدفت هذه الدراسة إلى تطوير إرشادات الخروج للمرضي الخاضعين لإستئصال الحويصلة المرارية بالمنظار الجراحي. وقد تم استخدام التصميم الوصفي الاستكثافي لإجراء هذه الدراسة. تم تنفيذ هذه الدراسة في أقسام الجراحة

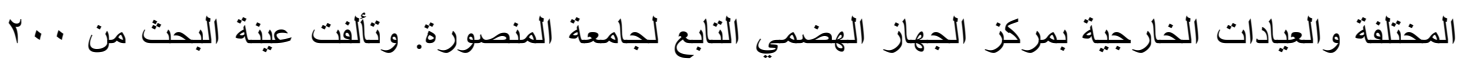
مريض بالغ ومتاح من كلا الجنسين وكانو ا يخضعون لإستئصسال الحويصلة المر ارية بالمنظار الجر احي في المكان السابق ذكره خلال مدة7شهور. وقد استخدمت ثلاثة أدوات لجمع البيانات:الأداة الأولي تتضمن إستمارة إستبيان بخصوص تقييم معلومات المرضي والأداة الثانية تشمل قائمة ملاحظة لتقييم ممارسات المرضي قبل وبعد العملية

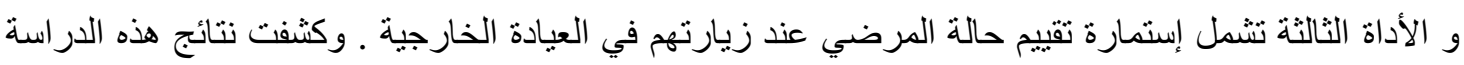

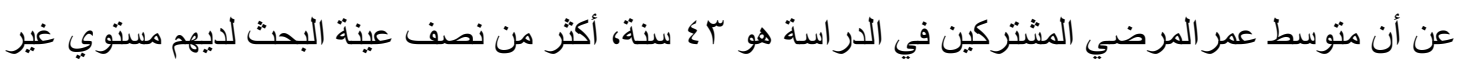
مرضي من المعلومات حول عملية إستئصسال الحويصلة المرارية بالمنظار الجر احي و العنايه ماقبل وبعد العملية و إرشادات الخروج ، كما أن معظهم حصلوا علي مستوي غير مرضي من الممارسات المتعلقة بفترة ماقبل وبعد

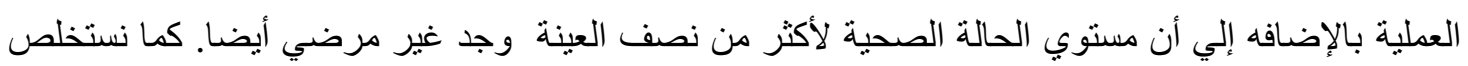
من هذة الدراسة إلي وجود علاقة بين معلومات المرضي وممارساتهم بالنسبة لخصائصهم الديموجر افية كما وجدت علاقة إيجابية ذات دلالة إحصائية بين معلومات المرضي وممارساتهم ومستوي الحالة الصحية لليهم ووقد أوصت هذه الدراسة إلي عمل أبحاث مستقبلية لدراسة العوامل التي تؤثر علي جودة الحياة للمرضي الخاضعين لإستنئصال الحويصلة المرارية بالمنظار الجراحي الحيل

الكلمات المرشدة : إستئصلال الحويصلة المرارية بالمنظار الجراحي ، المعلومات ، المعارسات ، إرشادات الخروج للمرضي 